\title{
Analysis of Flood Discharge Reduction in Karang Mumus River, Samarinda City, Indonesia
}

\author{
Riyan Benny Sukmara ${ }^{1,2}$, Ray-Shyan $\mathrm{Wu}^{3}$, Ariyaningsih ${ }^{4}$ \\ ${ }^{1}$ Department of Civil Engineering, National Central University, Chung-Li city, \\ 320, Taiwan \\ ${ }^{2}$ Department of Civil Engineering, Institut Teknologi Kalimantan, Balikpapan, \\ Indonesia \\ ${ }^{3}$ Professor, Department of Civil Engineering, National Central University, \\ Chung-Li city, 320, Taiwan \\ ${ }^{4}$ Department of Urban and Regional Planning, Institut Teknologi Kalimantan, \\ Balikpapan, Indonesia
}

\begin{abstract}
Flood issue in Samarinda almost surrounding every year, especially in the rainy season (October - April). Its issue depends on the several factors such as drainage condition, topographical area and also the problems of Karang Mumus river. This paper focused on the river problem. This river has decreasing capacity caused by constriction. Its affected by a lot of people live on the riverbank area and the worst of it is impossible to relocate all of them. In this study, we tried to analyze how to reduce the discharge. The analysis covered by hydrological analysis by using several scenarios. Most of the results exhibit the discharge of the river decrease than the current condition. The discharge decreased until $59,2 \%$ after scenario was applied.
\end{abstract}

Keywords : Discharge Reduction, Karang Mumus River, Flood Discharge 


\section{Introduction}

Flooding is one of most severe natural disaster often faces by humanity worldwide (Chaleeraktrakoon and Chinsomboon, 2015). Floods are a devasting kind of natural hazard (Zhang et al, 2014). A flood occurs when the overland flow of water inundate land and may cause damage to crops, damage to infrastructure, or event loss human lives (Samantha et al, 2016). Major population in Samarinda lives in the urban area. Therefore, it is necessary to analyze the flood issue of urban area. The result is valuable for guiding the government to propose the flood control strategy for this city. In this study, we focused on the Karang Mumus River, it is because the river is located along the city and the estuary is located in the center of this city. Thus, delta zones have become extremely vulnerable to flood (Tang et al, 2017).

River discharge developed by the rainfall and become a runoff on the surface land. Type of land surface affected the magnitude of the runoff. Most of the urban area has high runoff coefficient $(c)$, it is because the land surface covered by buildings, road, and public housing. Some of the runoff directly flows into drainage channel or was infiltrated and all of it becomes a discharge in the river. Thus, if the river capacity not sufficient, its can caused the flooding or inundation issue.

This study aims to estimate the total discharge in Karang Mumus Basin, which will flow into Karang Mumus River and analyze the discharge reduction to adapt the current condition where a lot of inhabitant lives on riverbank area so that its affected the river constriction.

\section{Study Area and Methods}

\subsection{Study Area}

The municipality of Samarinda located in Borneo island, Indonesia. A city about more than 820.000 inhabitants known as a capital city of East Borneo Province and became the center of government and economic activities. Total city area approximately $718 \mathrm{Km}^{2}$, is a riverside city on the edge of Mahakam River and Karang Mumus River (KMR).

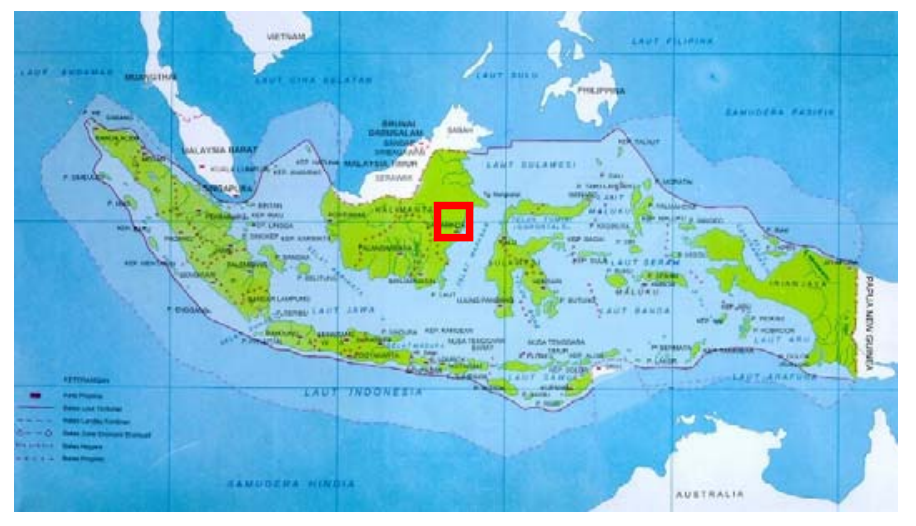

(a)

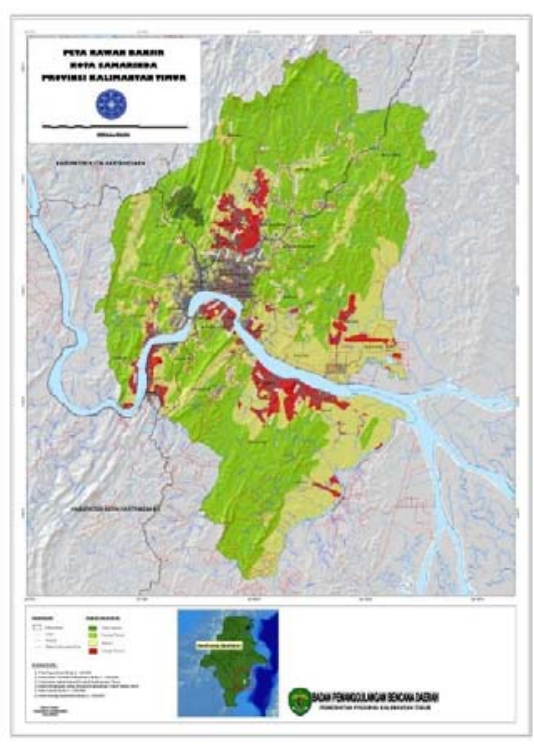

(b)

Figure 1 Map of Study Area : (a) Study location in the map of Indonesia; (b) Map of Samarinda City 
Analysis of Flood Discharge Reduction in Karang Mumus River, Samarinda City, Indonesia

Based on statictics, the characteristic of Samarinda's topography dominated by lowland area with $42,77 \%$ has located on the elevation 7-25 m above sea level.

Tabel 1 Altitude Distributions of Samarinda City

\begin{tabular}{|c|c|c|c|}
\hline No. & $\begin{array}{c}\text { Class of Altitude } \\
\text { (m above sea level) }\end{array}$ & Area $\left(\mathrm{Km}^{2}\right)$ & Percentage (\%) \\
\hline 1 & $0-7$ & 144,38 & 20,11 \\
\hline 2 & $7-25$ & 307,08 & 42,77 \\
\hline 3 & $25-100$ & 266,16 & 37,07 \\
\hline 4 & $100-500$ & 7,53 & 1,05 \\
\hline & Total & 718 & 100,00 \\
\hline
\end{tabular}

Samarinda also similar with the other common city, dominated by the building and residential area. Tabel 2, show the composition of city land use.

Tabel 2 Land Use Pattern of Samarinda

\begin{tabular}{|c|l|c|}
\hline No. & \multicolumn{1}{|c|}{ Type of Land Use } & Area $\mathbf{( K m}^{\mathbf{2}} \mathbf{)}$ \\
\hline 1 & Building and Yard & 178,98 \\
\hline 2 & Crop Field & 102,29 \\
\hline 3 & Field/Mooring & 107,74 \\
\hline 4 & Ponds & 0,86 \\
\hline 5 & Public Plantation & 49,0 \\
\hline 6 & Meadow & 0,75 \\
\hline 7 & Swamps & 7,3 \\
\hline 8 & Dry Land & 48,1 \\
\hline 9 & Light Protected Forest & 45,97 \\
\hline 10 & Heavy Protected Forest & 125,87 \\
\hline 11 & Other & $\mathbf{7 1 8}$ \\
\hline \multicolumn{2}{|c|}{ Total $\mathbf{( K m}^{\mathbf{2}} \mathbf{)}$} & \\
\hline \multicolumn{2}{|c|}{ Source : Regional Development Agency of Samarinda, 2002 } \\
\hline
\end{tabular}

According to the Table 1, exhibit that Samarinda City has an urban built-up area of $24,9 \%$ according to total area. With the composition above, its has high potential to develop runoff.

Samarinda influenced by 20 basins and Karang Mumus Basin is the largest. Most of a half area of Samarinda is included in Karang Mumus Basin (KMB), with approximaly of 365, $27 \mathrm{Km} 2$ (50,09\% of total area). KMB has a main river named Karang Mumus River (KMR). With total length is about $\pm 40 \mathrm{Km}$, KMR stretching from the north to south area of Samarinda. 


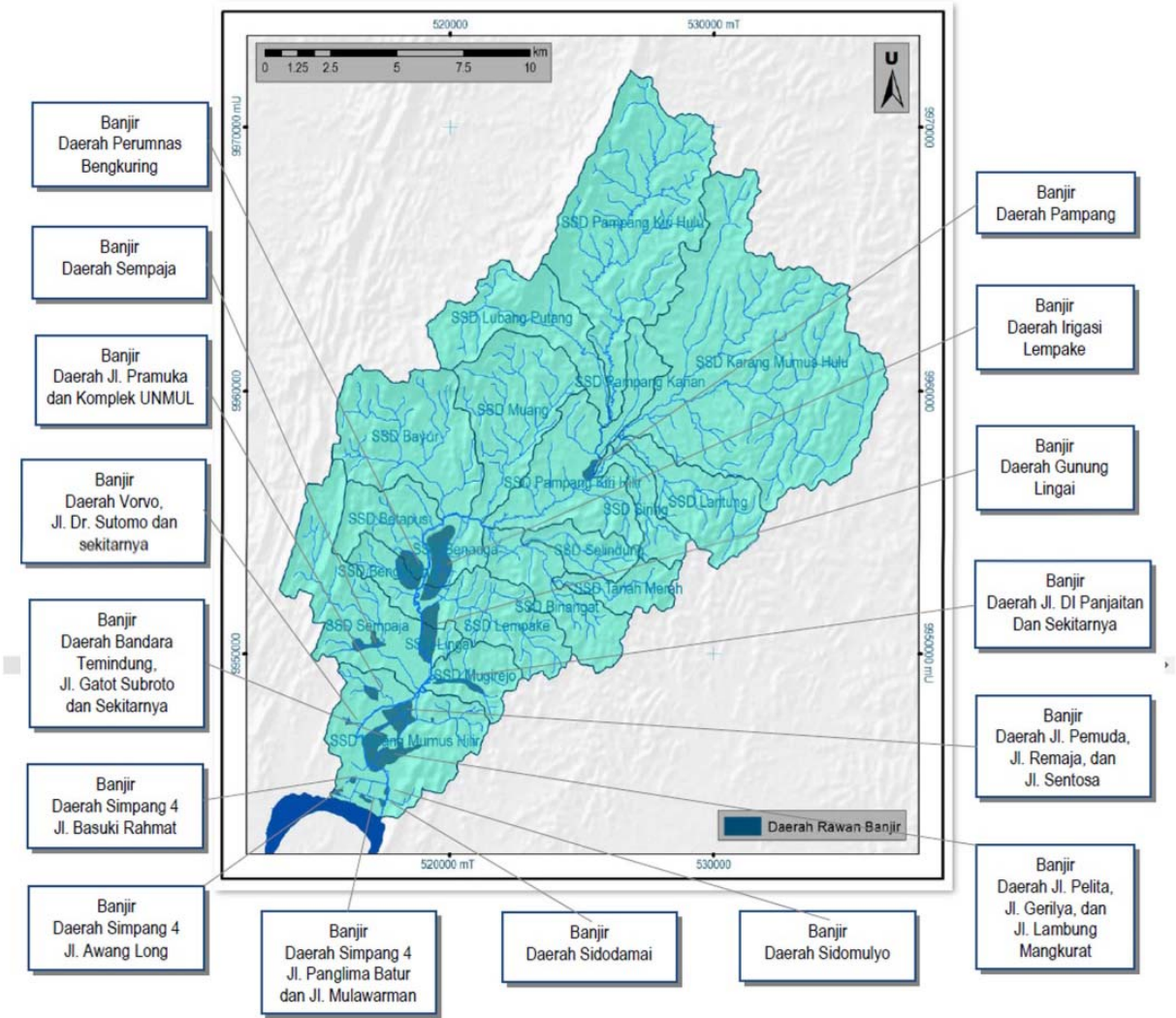

Figure 2 Karang Mumus Basin with Potential Area of Flooding (Ramadhani, Adi, 2013)

Based on statistical data, the average annual rainfall is more than $2691,8 \mathrm{~mm}$ (Samarinda Municipality in Figure, 2017). Based on Koppen Climate Classification, this rainfall amount included in $A f$ category, where it has precipitation treshold more than $60 \mathrm{~mm}$ (Kottek et al, 2006).

\subsection{Flooding Issue}

The main factor of flooding issue in Samarinda affected by incapacity of Karang Mumus River to flows discharge without overflowed. Incapacity caused by river constriction because people housing on the riverbank and silting. 


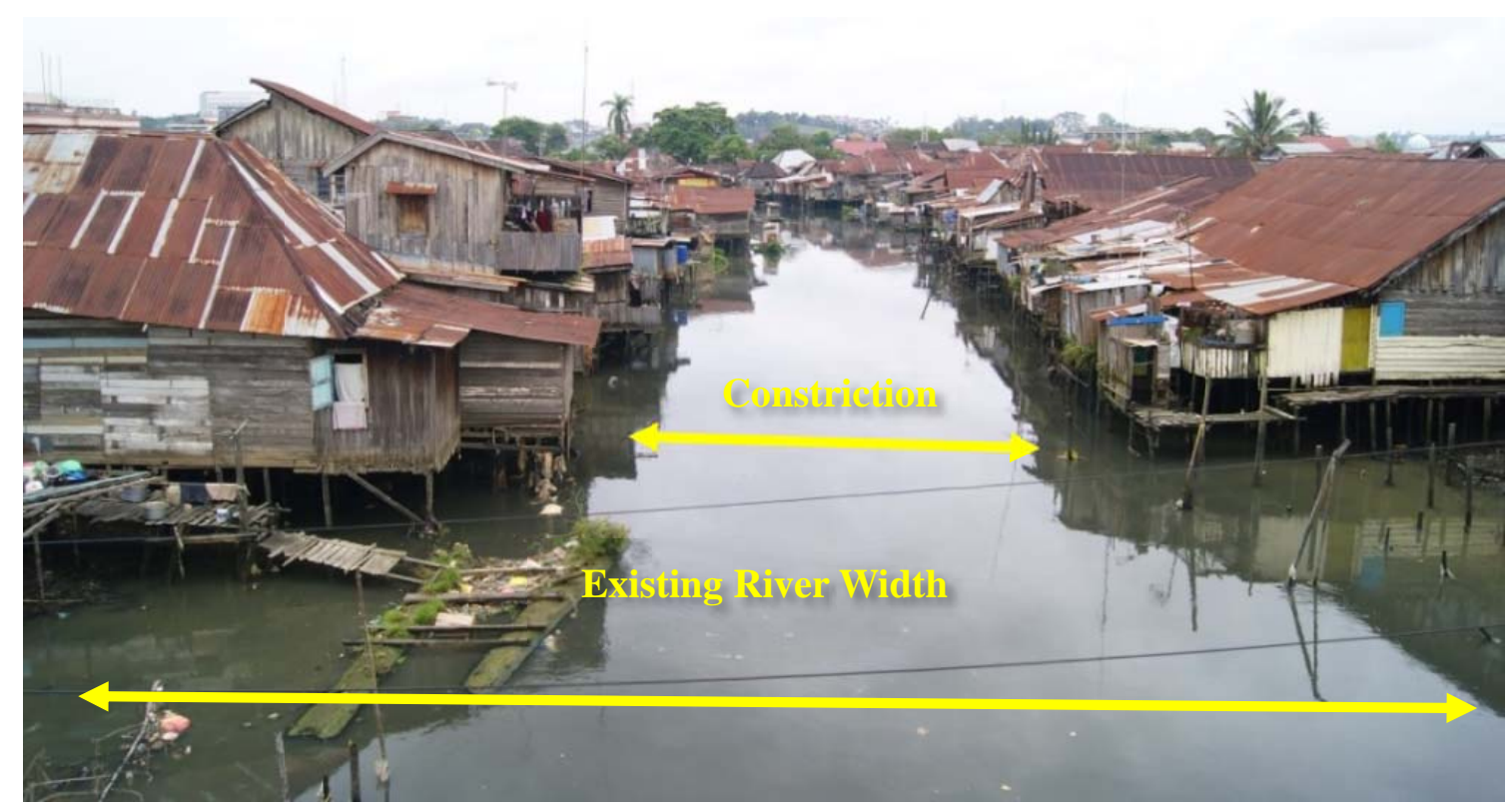

Figure 3 Existing Condition of Karang Mumus River, taken by author, 2015

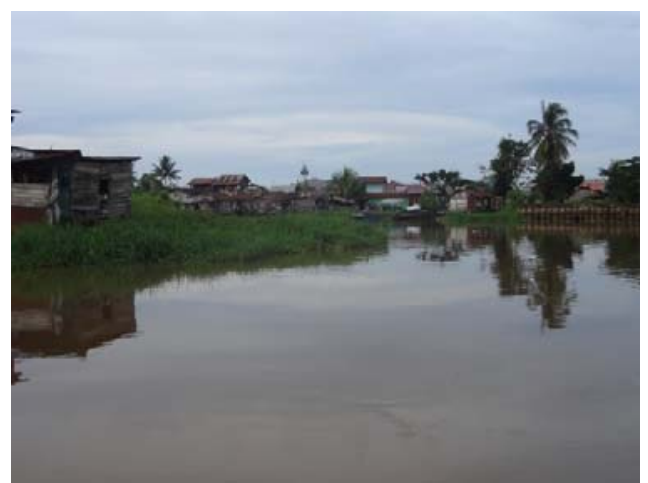

(a)

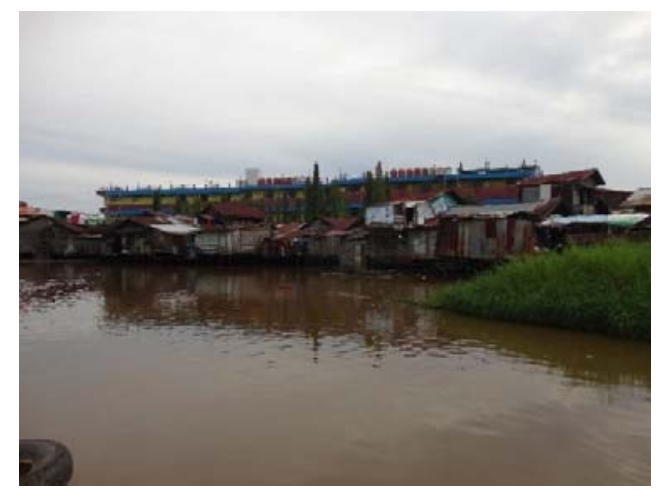

(b)

Figure 4 Sedimentation in the river

taken from Department of Transportation and Irrigation (DBMP) - Samarinda, 2015

Floods happen almost every year with various magnitudes. Its affected by high intensity of precipitation in Samarinda. It has significant influence of flooding. Regional daily newpaper (Tribun Kaltim, 2017) stated that the flooding inundated many regional locations in Samarinda City. The level of water surface reaches until $50 \mathrm{~cm}$. The worst floods located in the North part of Samarinda (Gunung Ligai). In this area, the estimated water surface level among $1 \mathrm{~m}$ to $1,5 \mathrm{~m}$ and causes more than 1000 public housing was flooded (Djumena, 2017). Floodings generate loss of economic and social order (Barros and Conde, 2017). 
2017 年環境資源永續發展研討會

Analysis of Flood Discharge Reduction in Karang Mumus River, Samarinda City, Indonesia

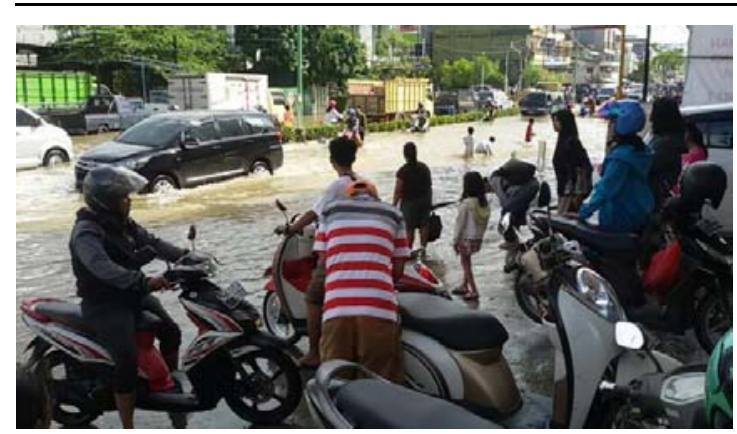

(a)

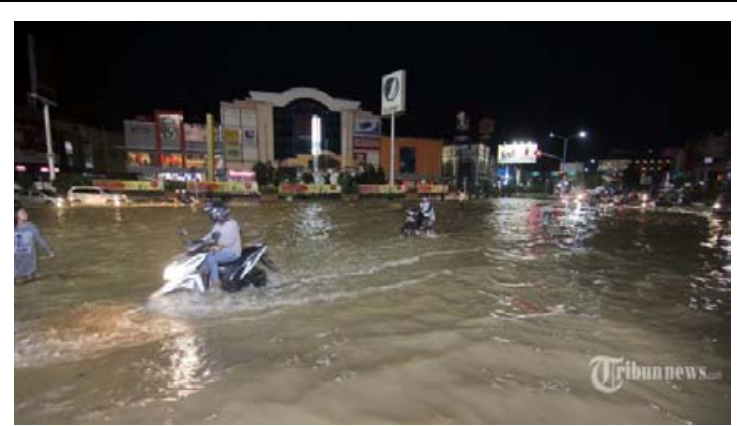

(b)

Figure 5 Flood in the center of the Samarinda City taken from www.tribunnews.com, April, 2017

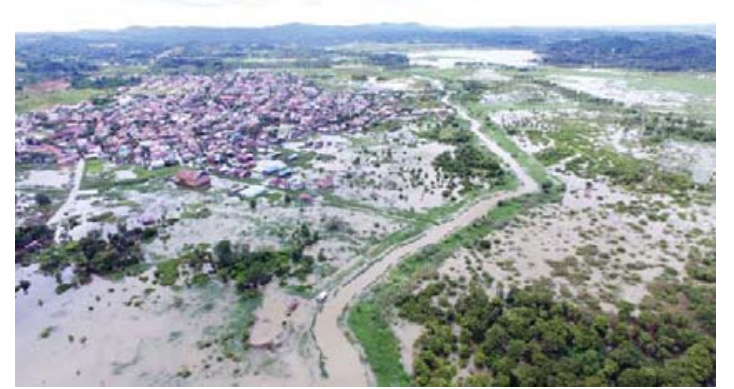

(a)

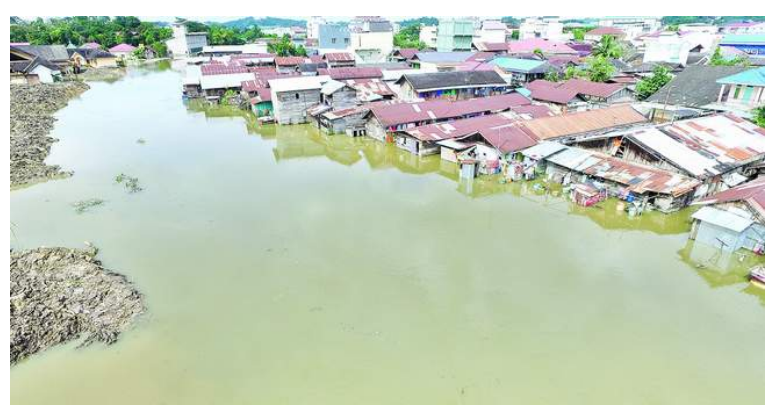

(b)

Source : www.tribunnews.com, April, 2017 Source :

http://kaltim.prokal.co/read/news/296592samarinda-darurat-banjir.html

Figure 5 Flooding in Samarinda : (a) Flooding at Banguring Residential Area (North part of Samarinda); (b) Overflow discharge (2017)

In order to flooding issues, the government tried to resolve by build the multipurpose Dam known as Benanga Dam and planned to built new dams to control the discharge. In this study focused on the reducing the discharge and analyze the response of water surface level in the river.

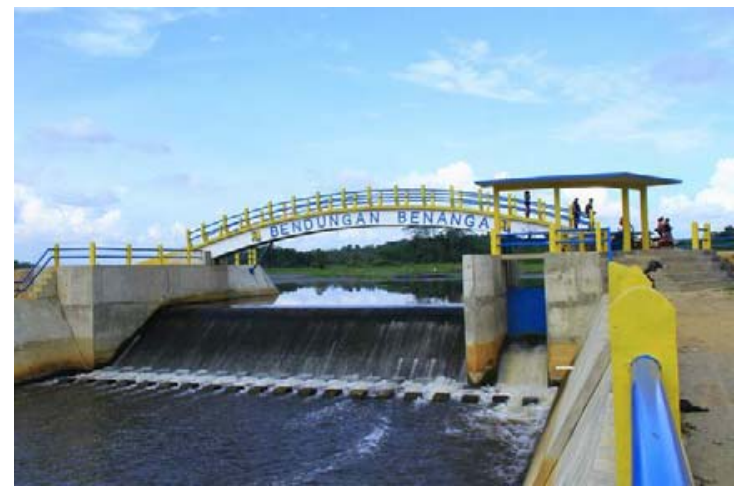

Figure 8 Benangan Dam (2016)

Source : http://kaltim.prokal.co/read/news/264958-terkait-relokasi-warga-wadukbenanga-disciptakot-hanya-sediakan-lahan.html 


\subsection{Methodology}

In this study, methodology was developed to estimate the total discharge generated by rainfall which will flows in the stream with various year periods. The analysis done by using hydrological method, including rainfall and water surface analysis through modeling software such as Hydrological Modeling System (HEC-HMS) and River Analysis System (HEC-RAS), respectively. Discharge calculated partially for eash sub-basin to known which sub-basin generates the highest discharge. Then, the result of discharge calculation used to know the response of the water surface level in the stream.

\subsubsection{Rainfall Analysis}

In this calculation, average rainfall generated by three gauges and the spatial distribution boundaries done through Thiessen Polygon method.

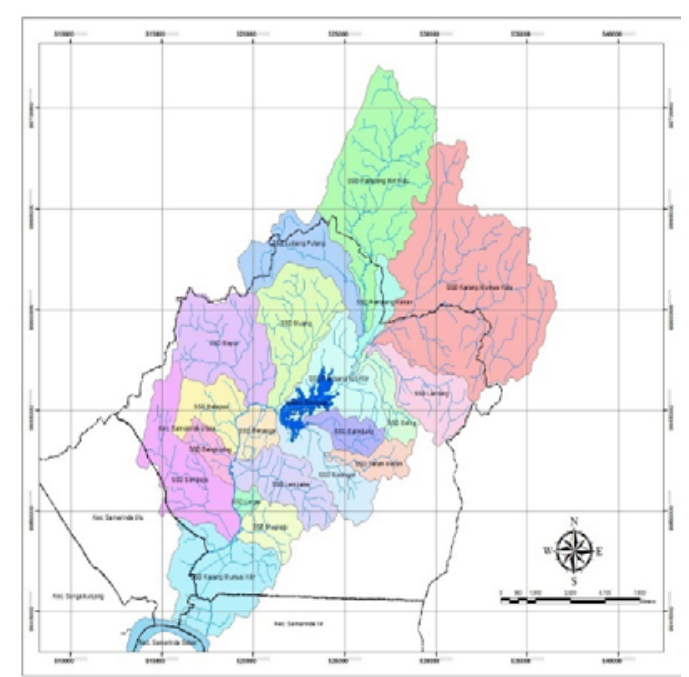

(a)

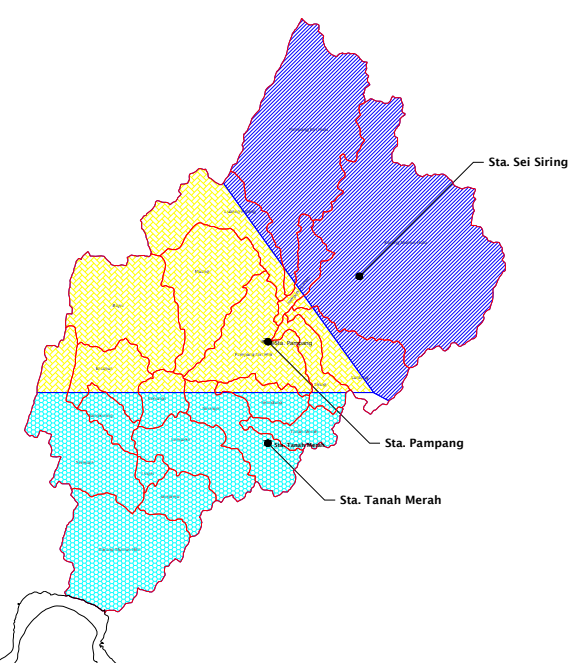

(b)

Figure 9 Karang Mumus Basin : (a) Distribution of sub-basin; (b) Thiessen Polygon Spatial Boundaries

Rainfall value generated from three gauges, Pampang, Sei Siring and Tanah Merah with range of time series data from 2004 until 2013. 


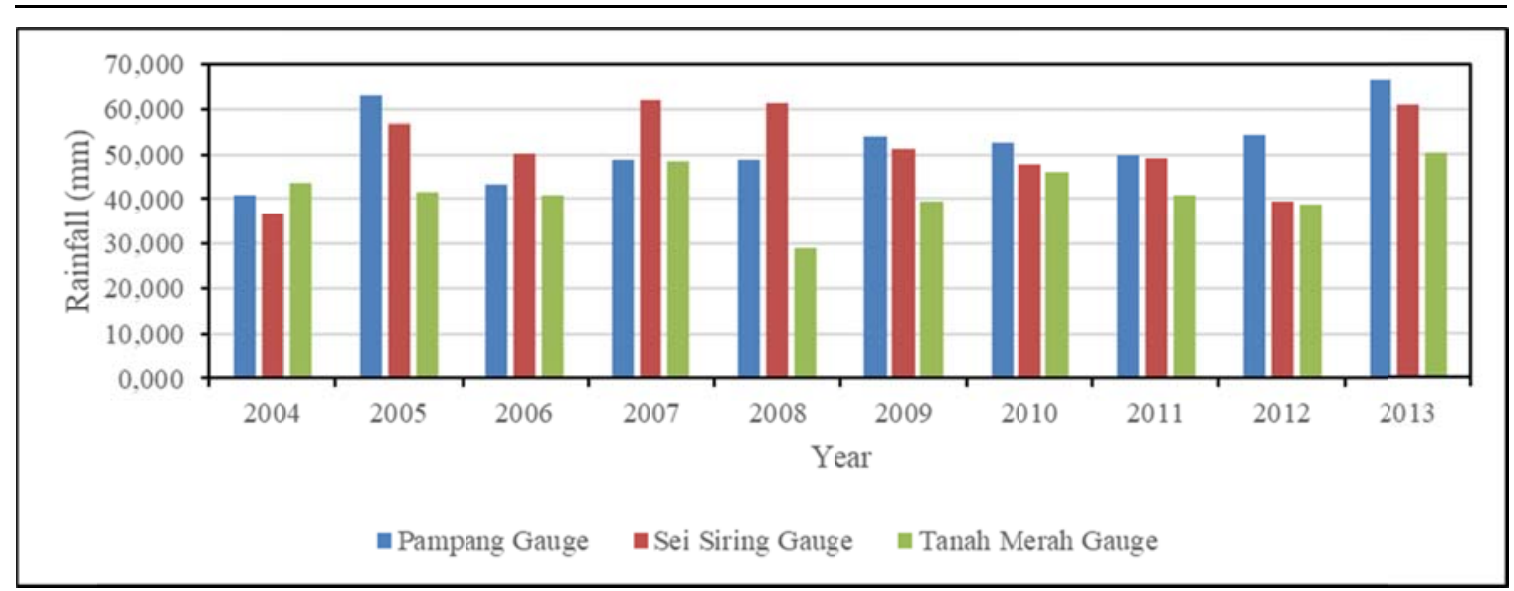

Figure 10 Maximum Average of Monthly Rainfall

Analysis of rainfall distribution was performed by several methods such as Normal, Gumbel and Log Pearson Type III. The following equation is (Soewarno, 1995):

Normal Distribution $\rightarrow X_{T R}=\bar{X}+K_{T} \times S$

Gumbel Distribution $\rightarrow X_{T R}=\bar{X}+S \times \frac{\left(-\ln -\ln \frac{T-1}{T}\right)-Y_{n}}{S_{n}}$

Log Pearson Type III $\rightarrow \log X_{T R}=\log X+K_{T} \times S \log X$

Standart deviation, $S=\sqrt{\frac{\sum\left(X_{1}-X_{2}\right)^{2}}{n-1}}$

where $X_{T R}$ is a rainfall prediction, $\bar{X}$ is average of variant, $T$ is year period and $K_{T}$ is frequency factor (Variable Gauss Reduction value)

After distribution is done, the result need to test for determine the suitable distribution which can be representating rainfall data. Test perform by goodness of fit test such as Chi Square and Smirnov-Kolmogorov method.

Chi Square Test $\rightarrow \chi_{h}^{2}=\sum_{i=1}^{G} \frac{\left(O_{i}-E_{i}\right)^{2}}{E_{i}}$ (Soewarno, 1995), where $G$ is total of sub-group (class interval); $O_{i}$ is total value of observation in sub-group $i$; $E_{i}$ is total of theoretical value of sub-group $i$. The interpretation if the probabilitation value of $\chi_{h}^{2}$ greater than $5 \%$, thus the distribution is accepted.

Smirnov-Kolmogorof method is a non-parametric test, so that the test did not use specific function (Soewarno, 1995). The interpretation can be accepted if the value of $D_{\max }$ less than $D_{O}$, where $D_{\max }=\left[P(X m)-P^{\prime}(X m)\right]$ and the $D_{O}$ is the critical value for degree of freedom of $5 \%$. 


\subsubsection{Discharge Analysis}

Hydrological analysis in this study was conducted by using HEC-HMS software developed by U.S. Army Corp. of Engineers (USACE). Hydrological modeling contains the several parameters such as basin and sub-basin area, rainfall data, river length, land surface coefficient and also the elevation-storage-discharge data from each sub-basin. The figure 11 shown the modeling setup equipped with symbol for sub-basin, junction, reaches and reservoirs.

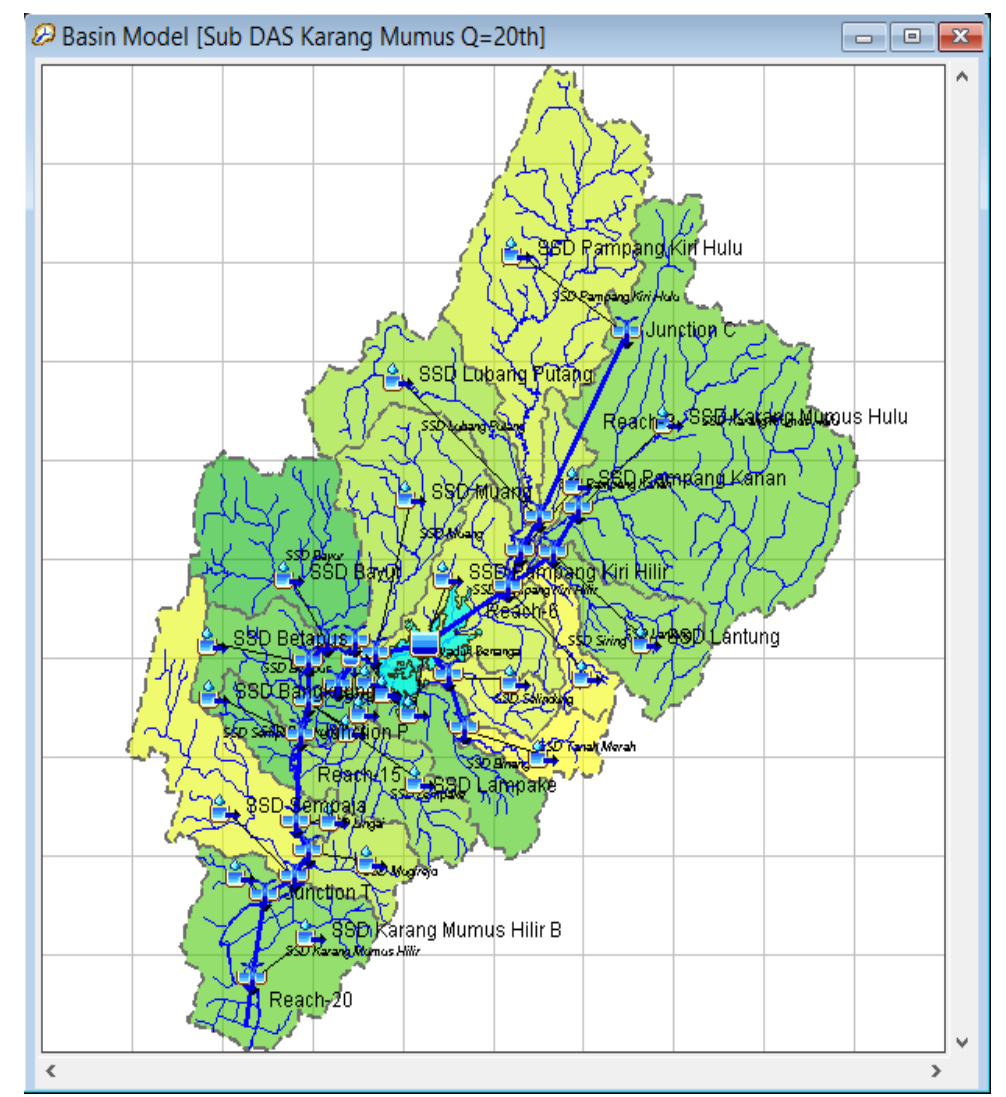

Figure 11 Hydrologic Model for Karang Mumus Basin, perform by HEC-HMS

Basin data component is needed to represents in the real condition. The SCS Curve Number method (SCS is Soil Conservation Service) was used to calculate how much water will infiltrated and became a runoff. The parameters such as initial abstraction, curve number, timelag and percentage of imperviousness (USACE, 2010).

Initial Abstraction $\rightarrow I_{a}=0,2 \times S$ and $S=\frac{25400-254(C N)}{C N}$, where $S$ is potential maximum retention and $C N$ is Curve number. The timelag difined as 0,6tc (E.I. Daniil, S.N. Michaas, 2005).

The reach routing method performed for simulate streamflow in this basin. Its parameter are length of reach, slopes, channel shape, and Manning Coefficient. In this paper, Manning coefficient was defined by using concept developed by Cowan, W.L. (1956). The grain roughness is represented by the size and shape of the grains of the material that form the stream bed (Chow, 1959). The following equation, reported by Chow 
to have been introduce by Cowan, can be used to compute the total Manning's roughness for a channel (Milhous, R.T. (2015) :

$n=\left(n_{g}+n_{1}+n_{2}+n_{3}+n_{4}\right) m$

where $n_{g}$ is the grain roughness, $n_{1}$ is roughness resulting from surface irregularities in the stream bed, $n_{2}$ is the roughness resulting from variations in shape and size of the channel, $n_{3}$ is roughness from obstructions, and $n_{4}$ is roughness from vegetation, and $m$ is correction factor for meandering or sinuosity of the channel.

\subsubsection{Discharge Reduction Scenario}

In this study, the discharge reduction scenario model was developed from several possible method. The $1^{\text {st }}$ scenario will try with normalization capacity of Benanga's Dam. The $2^{\text {nd }}$ scenario, discharge will reduce by several dam which the location of Dams provided by Samarinda's Government. The $3^{\text {rd }}$ scenario, reduction will perform by using several additional dams proposed by the existing topography condition. The model will simulate to know the amount of discharge reduction of each scenarios.

\section{Result and Disscussion}

Table 3 shows the largest discharge generated by Karang Mumus Hilir, total amount of discharge is 
2017 年環境資源永續發展研討會

Analysis of Flood Discharge Reduction in Karang Mumus River, Samarinda City, Indonesia

Table 13 Simulated Discharge of Karang Mumus Basin

\begin{tabular}{clcccccc}
\hline \multirow{2}{*}{ Code } & \multirow{2}{*}{ Sub-Basin } & Area & \multicolumn{5}{c}{ Discharge (m/s) } \\
\cline { 5 - 8 } & & $(\mathbf{k m 2})$ & $\mathbf{Q 2}$ & $\mathbf{Q 5}$ & $\mathbf{Q 1 0}$ & $\mathbf{Q 2 0}$ & $\mathbf{Q 5 0}$ \\
\hline 1 & SSD Karang Mumus Hulu & 69.530 & 58.2 & 89.8 & 108.1 & 123.9 & 142.6 \\
\hline 2 & SSD Pampang Kiri Hulu & 42.290 & 20 & 33 & 40.7 & 47.4 & 55.4 \\
\hline 3 & SSD Pampang Kiri Hilir & 16.840 & 25.7 & 30.1 & 32.5 & 34.5 & 36.7 \\
\hline 4 & SSD Pampang Kanan & 4.660 & 5.1 & 8.8 & 11.6 & 14.3 & 18 \\
\hline 5 & SSD Lubang Putang & 16.000 & 8.8 & 12.6 & 15.3 & 18.1 & 21.8 \\
\hline 6 & SSD Lantung & 12.580 & 5.2 & 11.7 & 17.3 & 23.2 & 31.6 \\
\hline 7 & SSD Siring & 5.620 & 6.8 & 8.8 & 10.3 & 11.7 & 13.5 \\
\hline 8 & SSD Selindung & 5.650 & 5.3 & 10.6 & 14.4 & 18.5 & 24.2 \\
\hline 9 & SSD Tanah Merah & 5.560 & 8.4 & 15.2 & 20.3 & 25.6 & 32.8 \\
\hline 10 & SSD Binangat & 11.990 & 22.2 & 37 & 47.6 & 58.1 & 72.1 \\
\hline 11 & SSD Muang & 19.340 & 22.4 & 29.8 & 35 & 40.1 & 47 \\
\hline 12 & SSD Bayur & 22.500 & 23.5 & 31.7 & 37.6 & 43.4 & 51.3 \\
\hline $13 \mathrm{~A}$ & SSD Benanga A & 1.060 & 2.3 & 3.9 & 5.1 & 6.3 & 7.9 \\
\hline $13 B$ & SSD Benanga B & 0.940 & 2 & 3.5 & 4.5 & 5.6 & 7 \\
\hline $13 C$ & SSD Benanga C & 1.280 & 2.6 & 4.3 & 5.6 & 6.8 & 8.4 \\
\hline $13 D$ & SSD Benanga D & 1.850 & 2.8 & 4.7 & 6.1 & 7.5 & 9.3 \\
\hline 14 & SSD Betapus & 9.330 & 17.7 & 21.4 & 23.9 & 26.4 & 29.8 \\
\hline 15 & SSD Lampake & 12.880 & 27.7 & 45.8 & 59.3 & 73.1 & 91.5 \\
\hline 16 & SSD Bangkuring & 4.330 & 7.1 & 12.3 & 16.1 & 20.3 & 26 \\
\hline 17 & SSD Lingai & 1.680 & 5.4 & 8.6 & 10.8 & 13.1 & 16.2 \\
\hline 18 & SSD Mugirejo & 6.780 & 26.6 & 41 & 51.3 & 61.6 & 75.4 \\
\hline 19 & SSD Sempaja & 20.260 & 36.2 & 59.4 & 76 & 92.6 & 115.6 \\
\hline $20 \mathrm{~A}$ & SSD Karang Mumus Hilir & 9.310 & 54 & 77.3 & 93.3 & 109.1 & 129.8 \\
\hline $20 B$ & SSD Karang Mumus Hilir & 14.240 & 70 & 99.3 & 119.4 & 139.4 & 165.7 \\
\hline
\end{tabular}

After simulate the discharce, hydraulics analysis was performed know the response of the river. The response simulated by 1-D modeling with HEC-RAS software. The simulation conducted in the main section of Karang Mumus river located after outlet of Benanga Dam. 


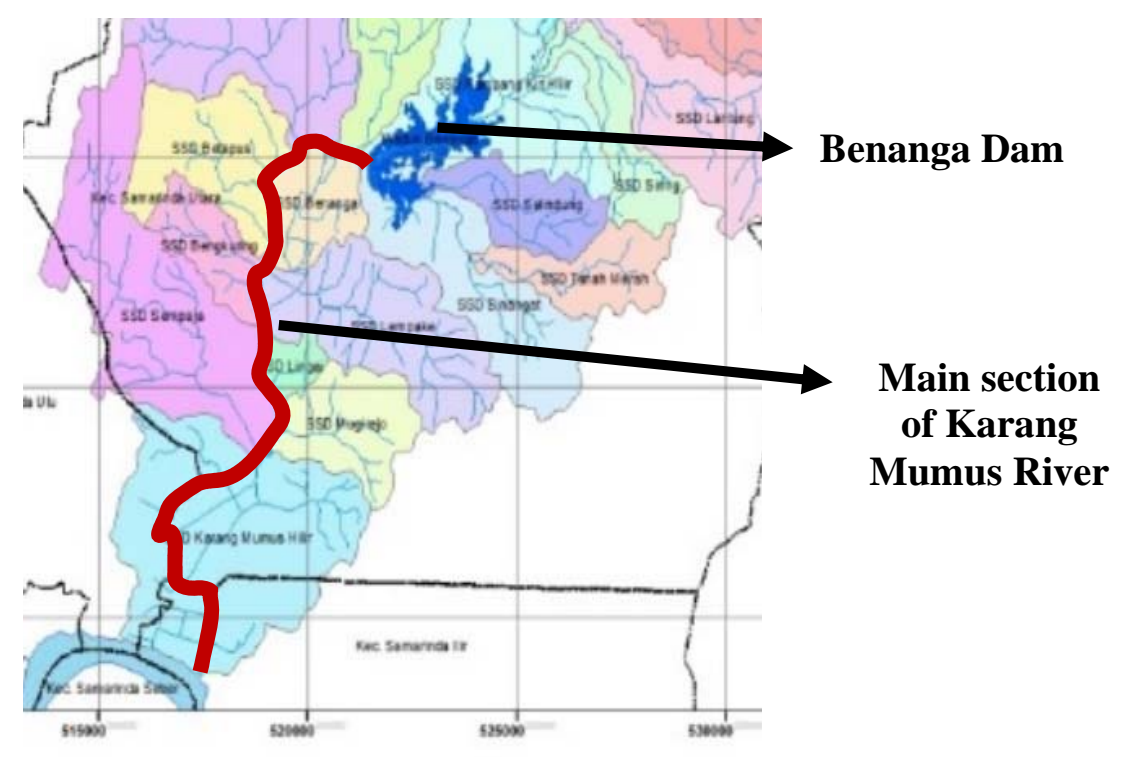

Figure 12 Location of Main Section of Karang Mumus River

By existing river cross sections, the simulation done by using discharge Q20 and show the water surface level is higher than the riverbank. It indicated that discharge was overflowed and became a flooding. Its also state that the not adequate to flows the discharge.

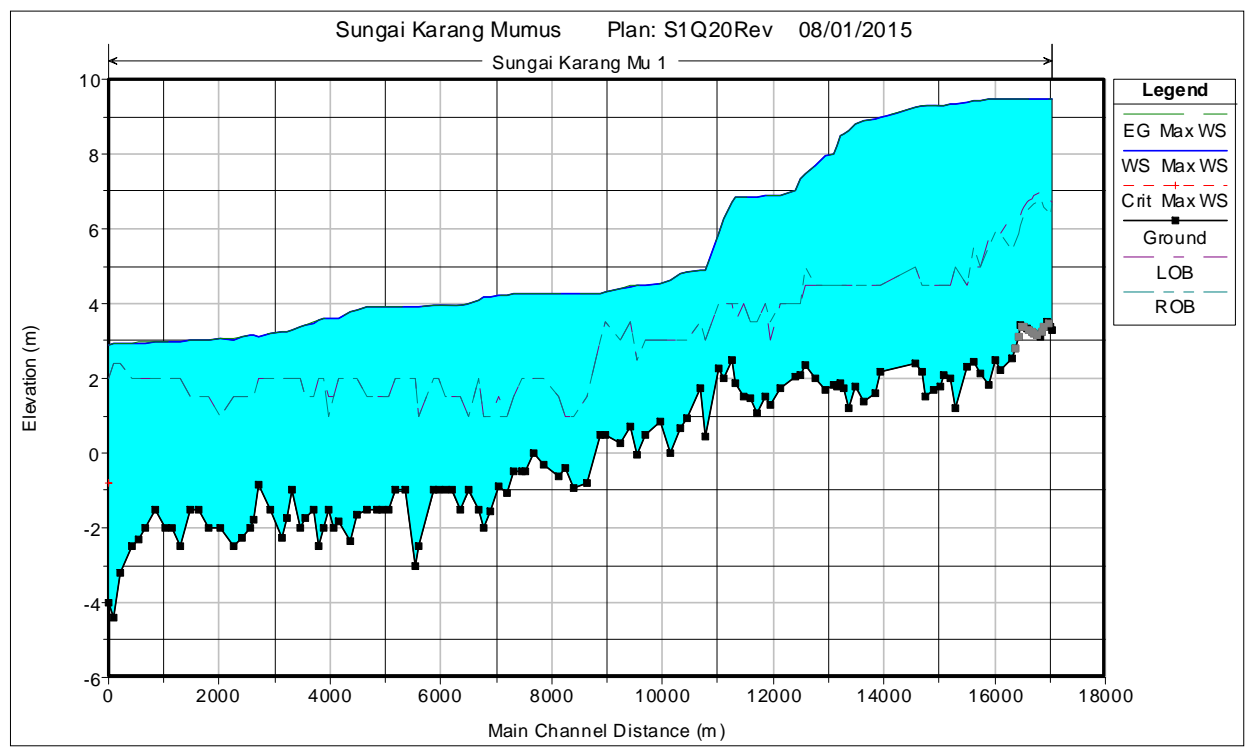

Figure 13 Hydraulics Simulation for Q20 (existing condition) 
2017 年環境資源永續發展研討會

Analysis of Flood Discharge Reduction in Karang Mumus River, Samarinda City, Indonesia

\subsection{Result of Scenario Simulation}

According to the result of hydraulics simulation show in Figure 12, the scenario was performed to reduce the discharge to minimize the water amount was overflowed.

\subsubsection{Scenario 1}

This scenario performed by try to normalize the capacity of Benanga Dam as the initial capacity. The initial capacity provided by capacity curve in year 2001 .

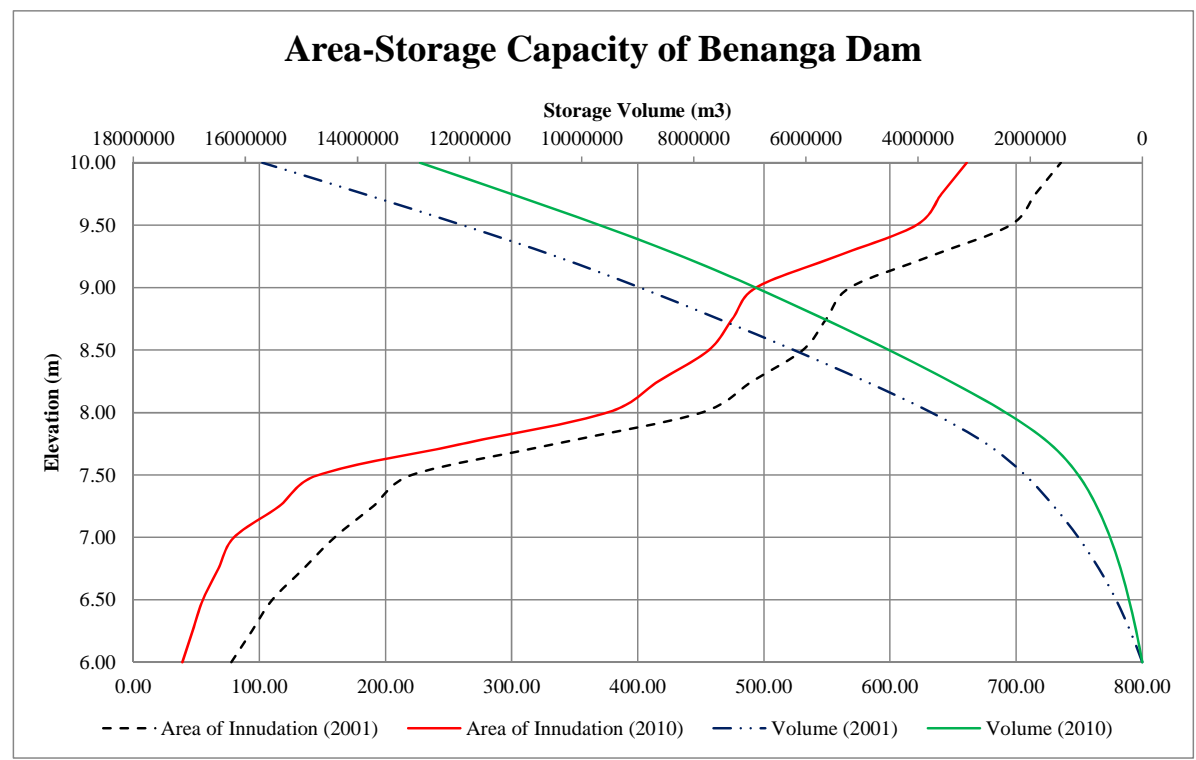

Figure 14 Area-Storage Capacity of Benanga Dam. 


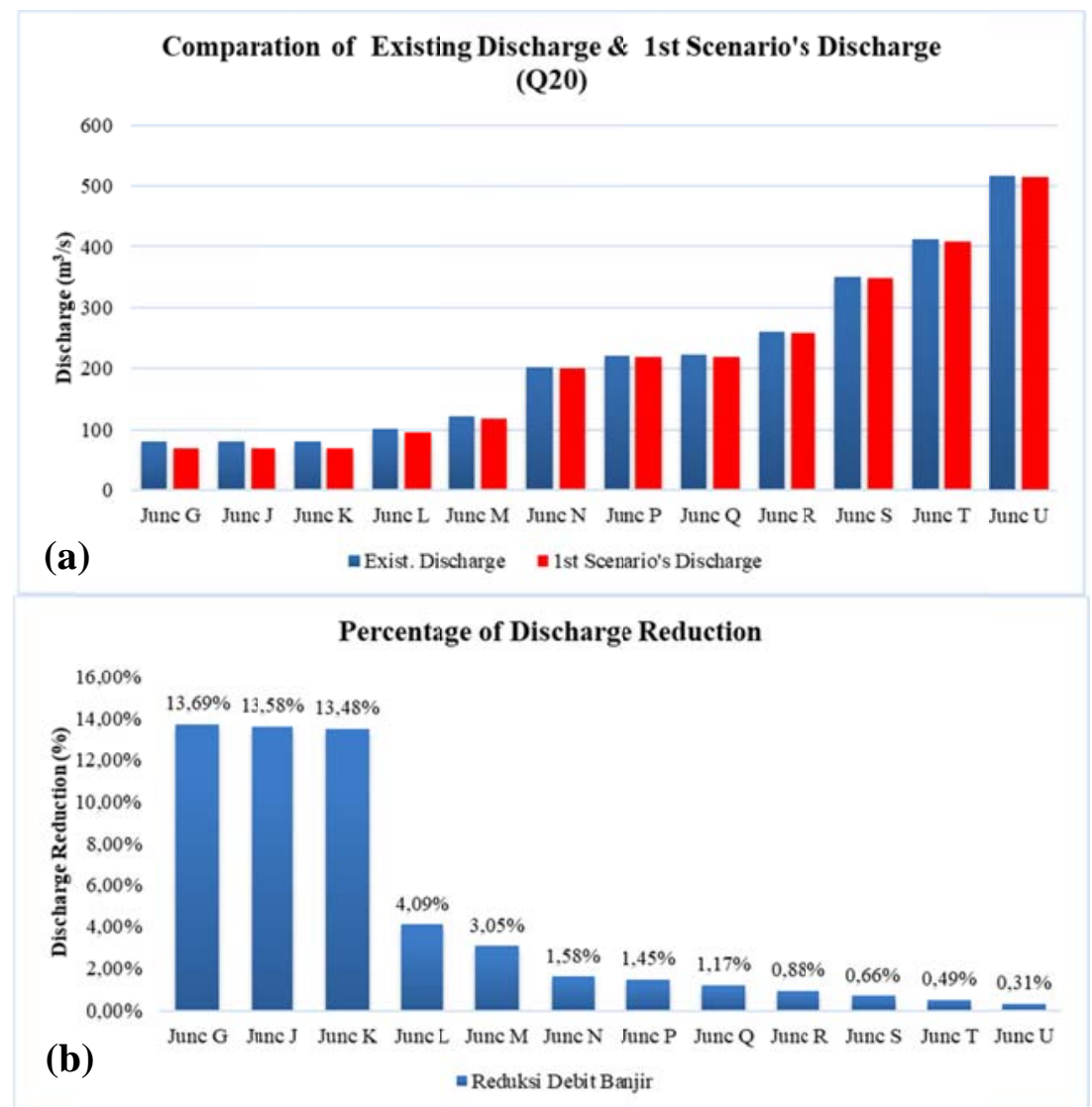

Figure 15 Scenario 1 Result : (a) Amount of discharge reduction; (b) Percentage of discharge reduction

According to the $1^{\text {st }}$ scenario result, shows that every junction has different value. Jucntion represent of the tributaries in the river. The $1^{\text {st }}$ scenario only reduce the discharge in the upstream are, exactly located after outlet of Benanga Dam.

\subsubsection{Scenario 2}

Scenario 2, performed based on the several new dams provided by Samarinda Government's plan. There are 6 dams spreaded in the Karang Mumus basin. Figure 16 show the location of Dams. 


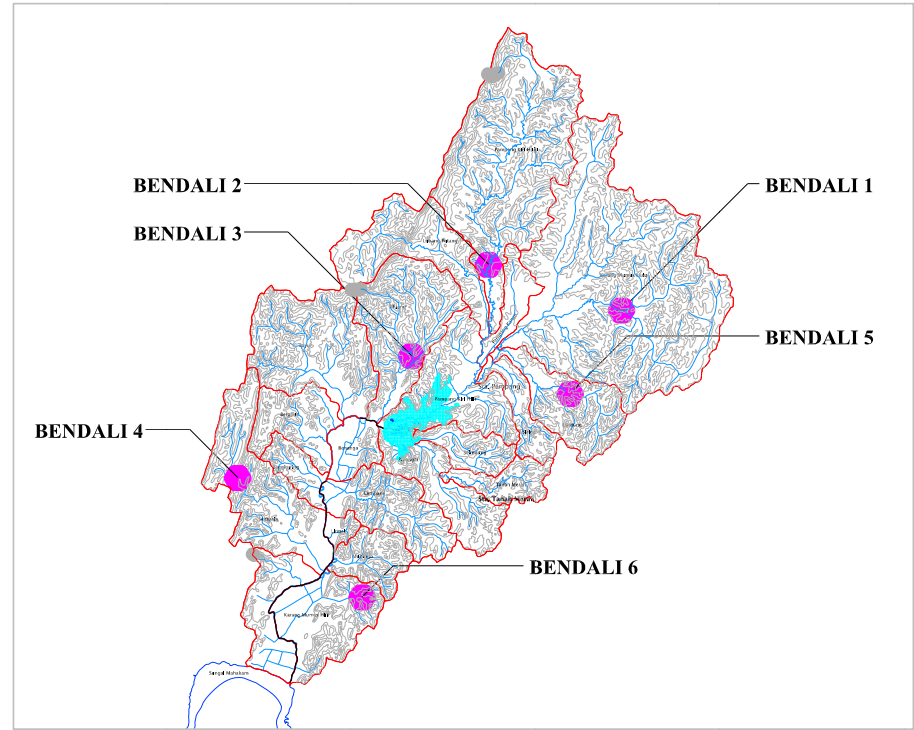

Figure 16 Dams Location of Scenario 2

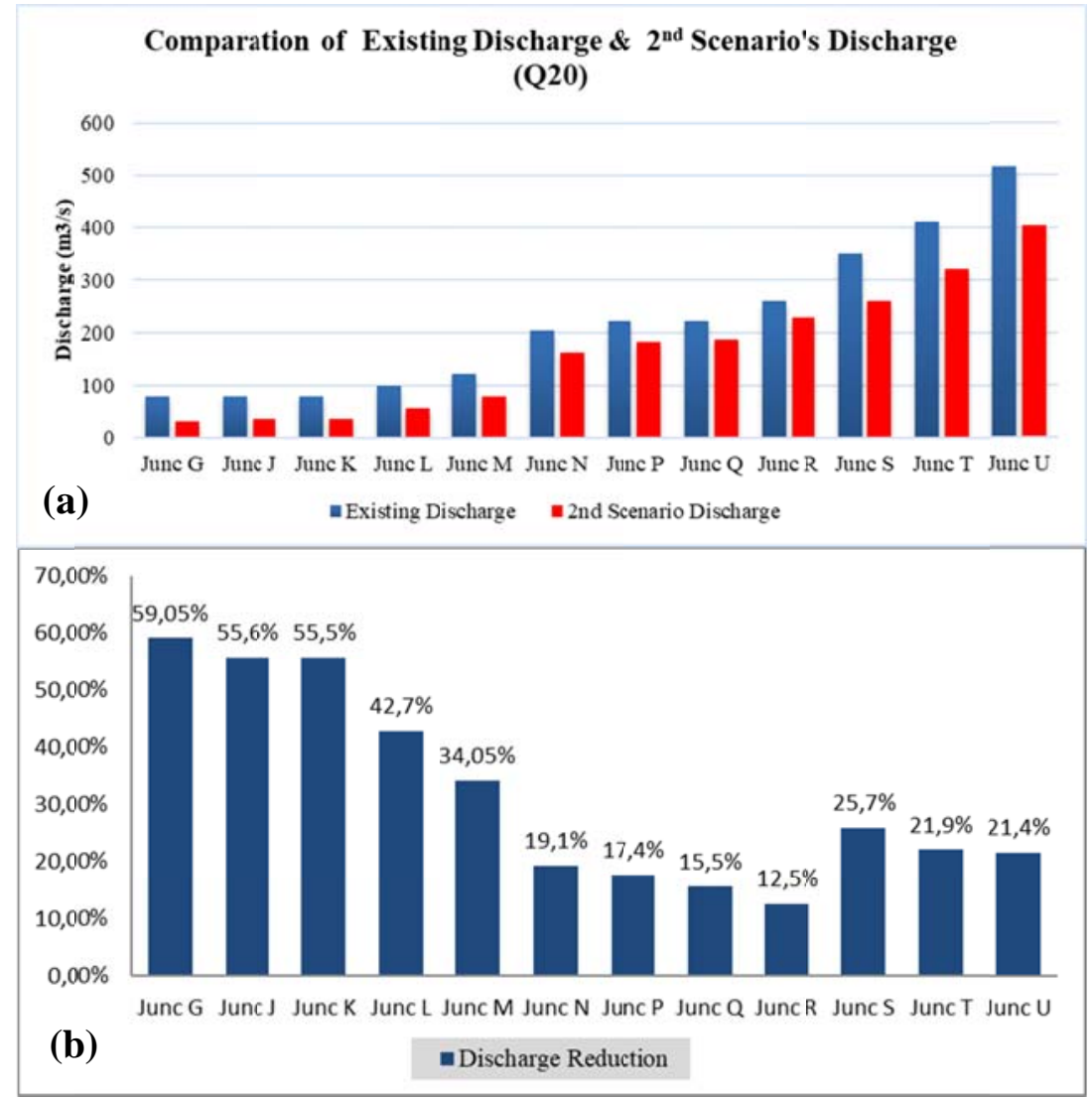

Figure 17 Scenario 2 Result : (a) Amount of discharge reduction; (b) Percentage of discharge reduction 
Figure 17 show that the result of Scenario 2 simulation can decreas the discharge with significant value of $59,05 \%$ in the Junction $G$ (outlet of Benangan Dam). It mean the dam 1, 2, 3 and 5 can reduce the discharge before enter to Benanga Dam.

\subsubsection{Scenario 3}

Scenario 3 was performed by adding several potential dams. Location of dams determinded by analyzed the potential topography where possible to build dams there. Parameters used to determine the location is upstream location which can be predicted to build dam with safely condition. All of dams assumed have total hight of spillway is $10 \mathrm{~m}$.

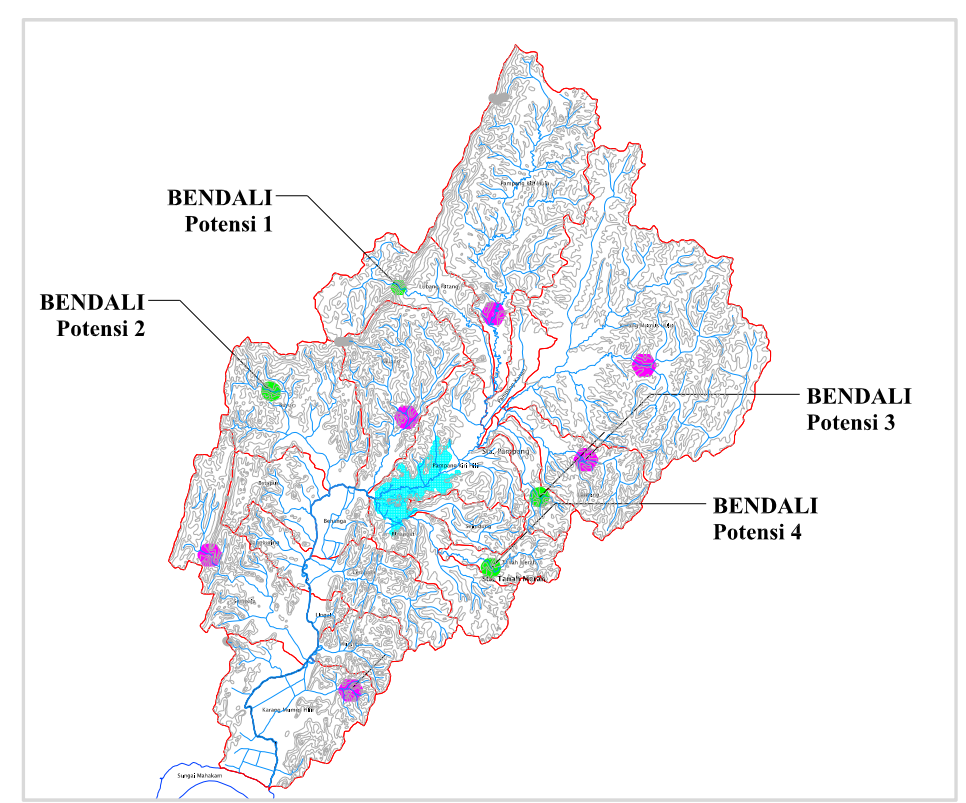

Figure 16 Dams Location of Scenario 2 


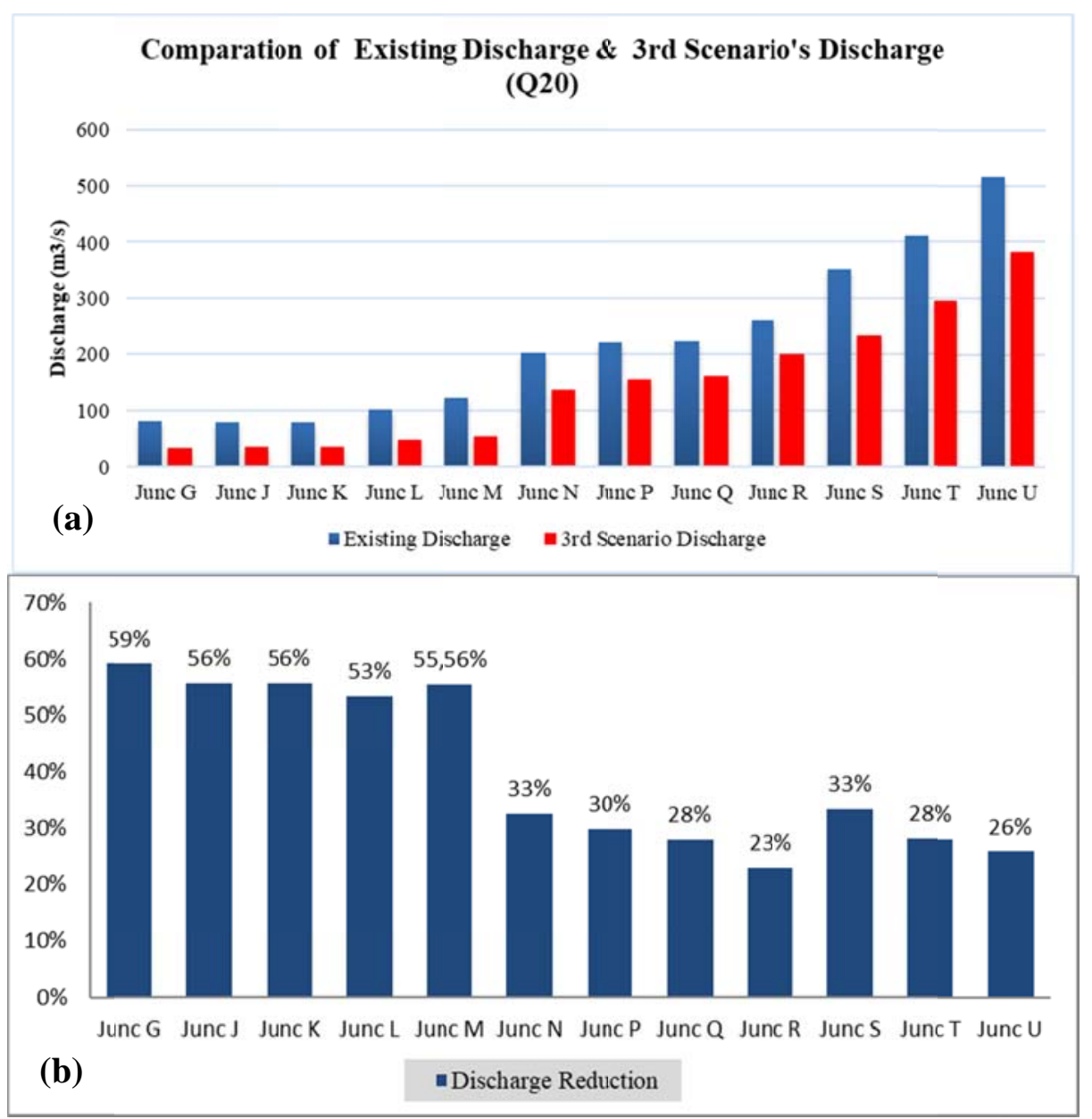

Figure 17 Scenario 3 Result : (a) Amount of discharge reduction; (b) Percentage of discharge reduction

The Scenario 3 exhibit the percentages of discharge reduction increase at the center and the downstream of Karang Mumus River. The average reduction from Junction $\mathrm{N}$ to Jucntion $U$ is $9,62 \%$ larger than Scenario 2. It means the Scenario 3 contribute significantly to reduce the discharge at downstream section.Thus, the scenario was used to find out the response of the water surface in Karang Mumus River, the result as shown as Figure 18. 
2017 年環境資源永續發展研討會

Analysis of Flood Discharge Reduction in Karang Mumus River, Samarinda City, Indonesia

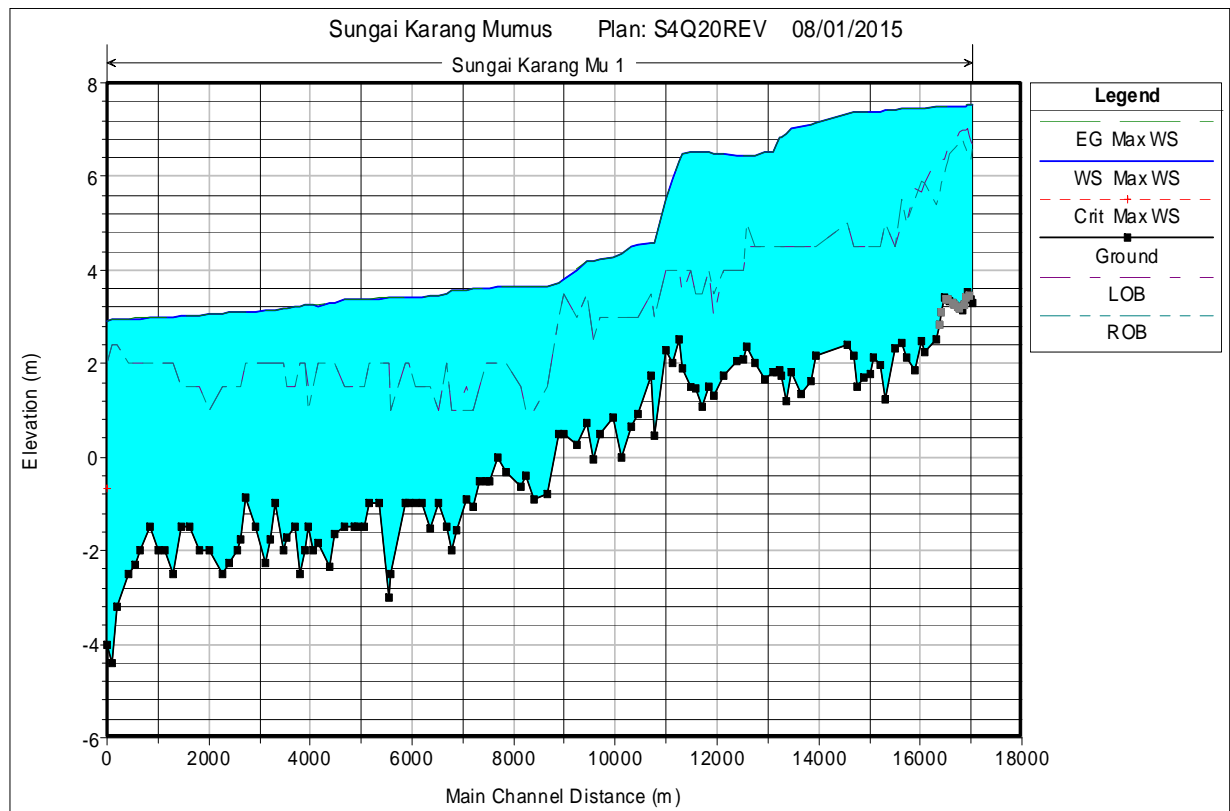

Figure 18 Water Level Response of Discharge of Scenario 3

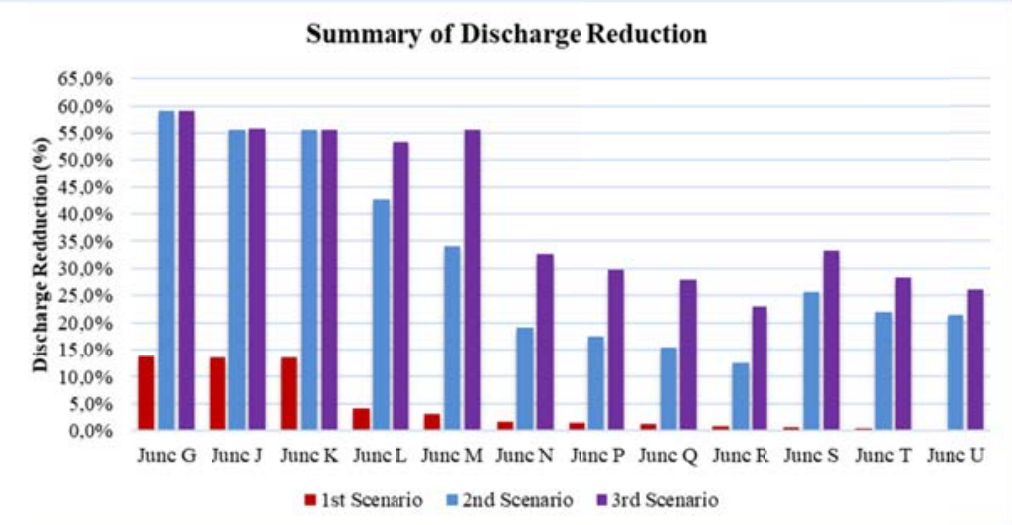

Figure 18 Summary of Discharge Reduction

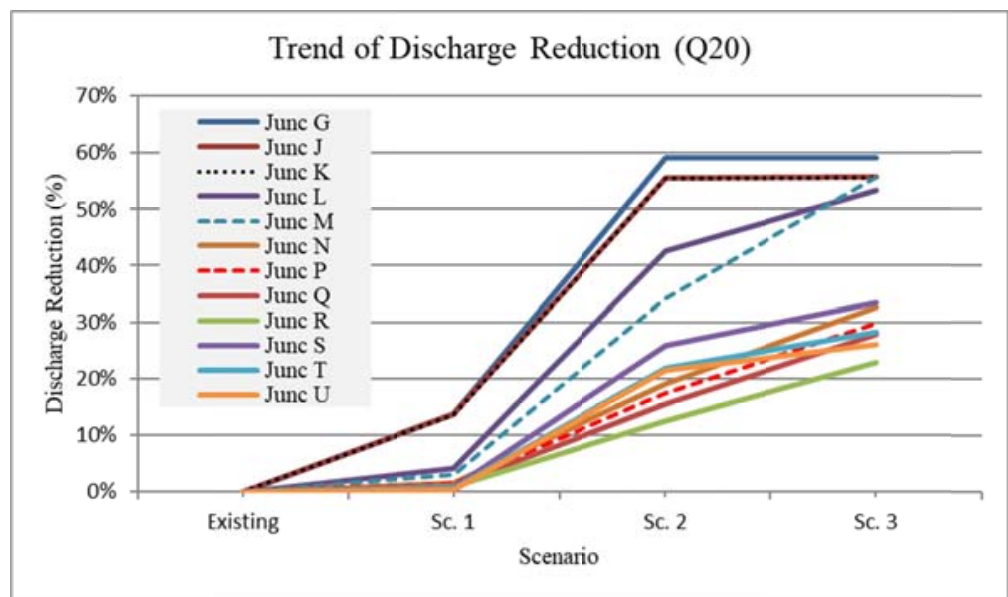

Figure 19 Trend of Discharge Reduction 


\section{Conclusions and Recommendations}

The total amount of discharge in Karang Mumus basin shown in existing condition simulation result of 516,4 m3/s. With the existing condition, river unable to flows discharge without overflow. River constriction gives the significant effect to decrease the river capacity.

Corresponding to result of simulations, the result has various percentages starting from $0,2 \%$ until $59,2 \%$ depend on the scenario was applied. It is shown in the junction $\mathrm{N}$ to Junction U (downstream area). The downstream area is the important because all activities whole the city is centered in this area. In the upstream area, discharge reduction is assisted the Benanga Dam to control the discharge in the downstream area ahead of the outlet.

This paper also proves the government's plan is quite effective to cope the flooding issue in Samarinda. Therefore, further research is needed to develop the complete strategy to resolve the flooding issue in Samarinda. This paper only provide the reduction value of reducing discharge. Future research will include the complete study about the possible way to increase the flood problem and control the discharge because is very difficult to relocate all the inhabitants from a riverbank. The flood control, especially in discharge reduction, need government contribution to create the policies for supporting the scenario.

For future study, the other way to control the discharge is by using some ponds to reduce it. But still needs to studied more deeply. The combination of increasing river capacity and good drainage system perhaps can be more promises solution to increase the result of discharge reduction.

\section{Acknowledgement}

The author wishes to thank Balai Wilayah Sungai (River Basin Agency) Kalimantan III, Department of Drainage and Irrigation of Samarinda (DBMP, Samarinda) for the support of data in this study and also National Central University for the scholarship.

\section{References}

[1] Barros, Mario T. L. and Conde Flavio. Urban Flood Warning Systems Social Benefits. World Environmental and Water Resources Congress (2017), Sacramento, USA. DOI: 10.1061/9780784480601.054

[2] Bruner, Gary W. HEC-RAS, River Analysis System Hydraulic Reference Manual. U.S. Army Corp. of Engineers. Davis. USA.

[3] Chow, V.T. Open-channel Hydraulics. McGraw-Hill, (1959).

[4] Chaleeraktrakoon, C., Chinsomboon, Y. A Flood Prediction Model for Adapting Flood Control Rule Curve of Multipurpose Dam. World Environmental and Water Resources Congress - ASCE (2015). doi:10.1061/9780784479162.244

[5] Cowan, W. L. Estimating Hydraulics Coefficients for Natural Stream Channels with Vegetated Banks. Agriculture Engineering, Vol. 37, no.7,pp 473-475. (1956)

[6] Djumena, Erlangga. Banjir Landa Samarinda, 1000 Rumah Terendam. Retrieved from http://regional.kompas.com (2017)

[7] Feldman, Arlen D. (ed). HEC-HMS Technical Reference Manual. U.S. Army Corp. of Engineers (USACE). Davis. USA.

[8] Kottek, M., Grieser, J., Beck, C., Rudolf, B., and Rubel, F. World Maps of KoppenGeiger Climate Classification Updated. Meteorologische Zeitschrift, Vol. 15, No. 3, 259-263 (2006). doi: 10.1127/0941-2948/2006/0130 
[9] Milhous, Robert T. On Grain Roughness in River and Streams. Hydrology Days (2015)

[10] Ramadhani, Adi. Pemodelan Hidrologi untuk Penentuan Tingkat Prioritas Sub Sub DAS Dalam Pengendalian Banjir Menggunakan Citra Pengindraan Jauh dan Sistem Informasi Goegrafis (Studi Kasus : Sub DAS Karang Mumus Samarinda), Universitas

Gajah Mada, Yogyakarta, Indonesia (2013)

[11] Samanta, S., Koloa, C., Pal, D. K., \& Palsamanta, B. Flood Risk Analysis in Lower Part of Markham River Based on Multi-Criteria Decision Approach (MCDA). Hydrology, 3, 29 (2016). doi:10.3390/hydrology3030029

[12] Soewarno. Hidrologi “Aplikasi Metode Statistik untuk Analisa Data Jilid I. Nova. Bandung. Indonesia (1995)

[13] Tang Y., Guo, Q., Su, Chengjia, and Chen X. Flood in Delta Areas Under Changing Climate : Response of Design Flood Level to Non-Stationary in Both Inflow Floods and High Tides in South China. Water, 9, 471 (2017). doi:10.3390/w9070471

[14] Zhang J. Q., Jiang L., Liu, X., and Tong, Z. Flood Disaster Risk Assesment of Rural Housings-A Case Study of Kouqiang Town in China. International Journal of Environmental Reseach and Public Health, Vol. 11, pp 3738-3802, (2014). doi:10.3390/ijerph110403787 